\title{
The Klumpke Family - Memories by Doctor Déjerine, Born Augusta Klumpke
}

\author{
Julien Bogousslavsky \\ Department of Neurology, University of Lausanne, Lausanne, Switzerland
}

\section{Key Words}

Augusta Déjerine-Klumpke · Autobiographical

document $\cdot$ Jules Déjerine

\begin{abstract}
In this paper, we present a translation of an unpublished autobiographical document by Augusta DéjerineKlumpke, reporting her early years before she came to Paris to study medicine, when she was able to become one of the first women in France to hold a hospital position, as an extern and an intern. This American-born girl later married Jules Déjerine, who was to become the second successor to Charcot at La Salpétrière 23 years later. The present document gives a vivid account on the preceding years, and emphasizes the extraordinary dynamism and enthusiasm of a young woman, whose efforts and contributions influenced neurology at the turn of the 20th century, and dramatically changed the role of women in medical careers.
\end{abstract}

Copyright $\odot 2005$ S. Karger AG, Basel

\section{Introduction}

Augusta Déjerine-Klumpke (1859-1927) is mainly known for being the wife of Jules Déjerine (fig. 1), the second successor of Charcot at the 'Clinique des Maladies du Système Nerveux' at La Salpétrière in Paris, and for her thorough description of radicular palsies in inferior brachial plexus injuries in 1886 . However, she also became famous for her active role in the development of hospital careers for women physicians in France, being with the Englishwoman Blanche Edwards the first woman to become first an extern and then an intern in Paris. Augusta Déjerine-Klumpke was an American. She came from San Francisco (fig. 2), and had first studied in Germany and Switzerland, before moving with her mother and sisters to Paris, in order for her to become a physician. While she never became a professor of neurology, she was Jules Déjerine's major support during his academic years, and she has also remained famous for her critical and spectacular role during the 'Quarrel of aphasia', which opposed Déjerine to his future successor at La Salpétrière Pierre Marie. Like Déjerine a pupil of Vulpian, she was never completely accepted in the Paris neurological school which mainly included pupils of Charcot, and when Pierre Marie took over the chair at La Salpétrière, she had to leave to another hospital.

Her life is an exceptional witness of the early years of neurology in France, as well as of the fight, in which women had to involve themselves in order to have access to extern and intern positions in hospitals. While several of her friends and pupils (including her own daughter Mrs Sorrel-Déjerine) have reported interesting aspects of this unusual career, we have been able to trace an unpublished autobiographical document by Augusta DéjerineKlumpke herself (written in French), on her early neuro-

\section{KARGER \\ Fax +4161306 1234 E-Mail karger@karger.ch} www.karger.com
(C) 2005 S. Karger AG, Basel 0014-3022/05/0533-0113\$22.00/0

Accessible online at: www.karger.com/ene
Julien Bogousslavsky, MD

Department of Neurology, University of Lausanne

$\mathrm{CH}-1011$ Lausanne (Switzerland)

Tel. +412131412 20, Fax +41213141231

E-Mail julien.bogousslavsky@chuv.hospvd.ch 


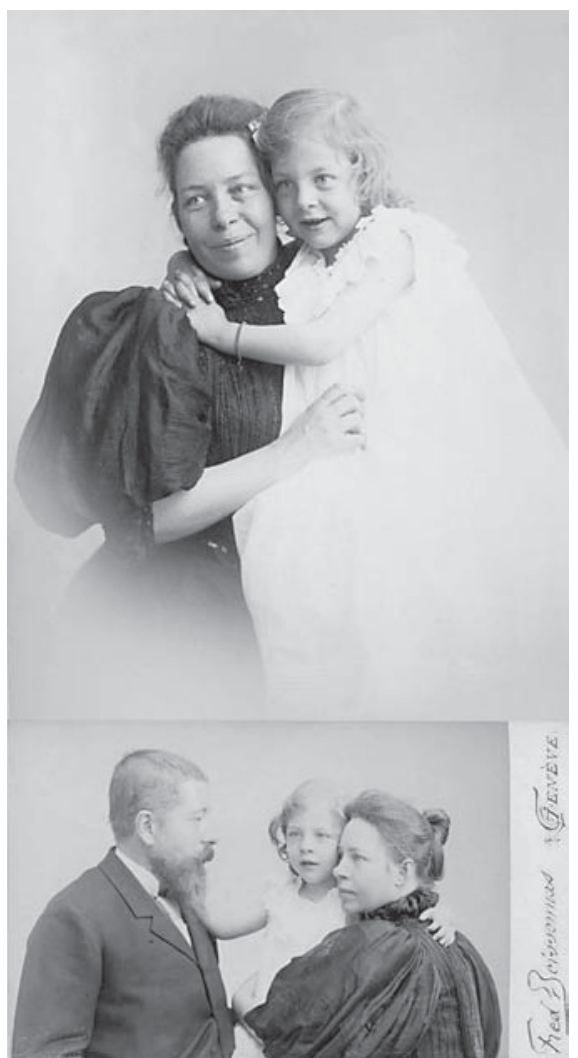

Fig. 1. Jules and Augusta Déjerine with their daughter Yvonne in 1893-1894 (photo Fred Boissonnas, Geneva, courtesy of J.-C. Sorrel-Déjerine).

logical years. Thanks to her grandson Jean-Claude SorrelDéjerine, who has given us the authorization to present it in an English translation. This invaluable document will be of great help for a better understanding of the developments of neurology and medicine during the last third of the 19th century.

\section{Translation of the Original Text}

My father, John Gerard Klumpke, American citizen who was born on February 26, 1825, in Suttrup, an English province, was raised in New Orleans, where he went to College and followed professional courses, as it was usual a long time ago in the colonies. He also followed courses in medicine.

He was intelligent, thriving, healthy and hard-working. He moved to the Far West at the age of 24, during the Californian 'Gold rush'. However, he quickly left the 'prospectors', in order to buy and sell real estates in San

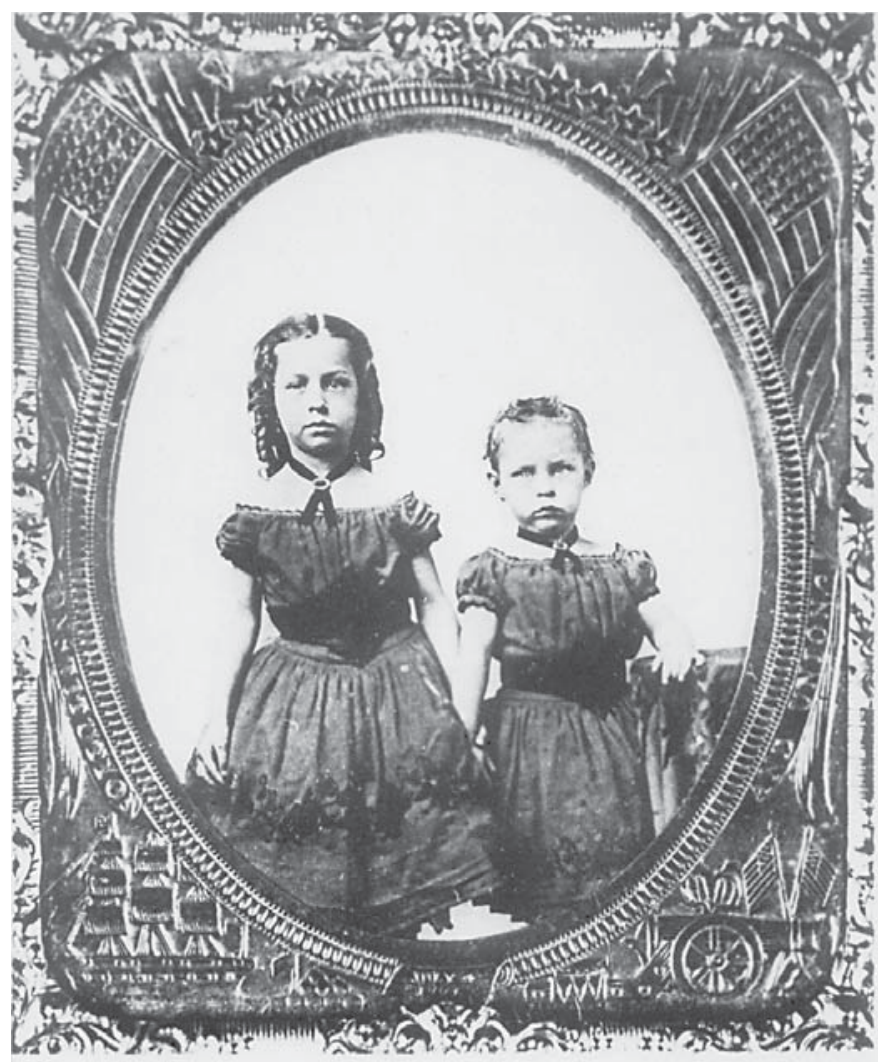

MADAME DEJERINE ET SA SQUR MISS ANNA RLUMPKE, RNFANTS. San-Francitico 1864 .

Fig. 2. Augusta and Anna Klumpke in San Francisco, 1864 (courtesy of J.-C. Sorrel-Déjerine).

Francisco. The professional courses which he had followed, as well as the medical knowledge he had acquired, were very helpful to him in this early time in San Francisco.

He was registered on August 20,1850, as one of the first 'territorial pioneers' and member of the 'Vigiland Society' of San Francisco. He lived there for nearly 70 years and died on December 16, 1916, at the age of 93, with full intelligence capacity. He had seen the extraordinary development of San Francisco, which was only a small Spanish mission on dunes when he had arrived in 1849. Until his death, he was considered by his fellow citizens as a first-class businessman, as the man who best knew the history of San Francisco, and who was always 
called for when there were conflicts or discussions about land trade.

My mother, Dorothea Mathilda Tolle, was born in New York on March 21, 1835. She went to San Francisco in 1853 together with her sister, who was rejoining her husband, who had shortly established himself in San Francisco as a gunsmith. She met my father and married him on October 28, 1855. From this love marriage, four daughters were born, in 1856, 1859, 1861, 1863, of whom I am the second one. My elder sister made an unfortunate fall at 3.5 years, and suffered femoral fracture. A second fall at 5 years led to osteomyelitis with purulent knee arthritis. She remained handicapped, to my parents' despair. After looking without success for help in California, my parents decided to consult Professor Nélaton in Paris and Professor Langenbeck in Berlin. With her four children and one of her sisters, my mother went by boat to Europe in 1866. In Paris, Nélaton did not give her much hope. She went to Berlin, where the child was treated for 1.5 years in a clinic before a stay at the Kreusnach thermal baths was advised.

During her stay in Germany, my mother had private lessons given to her handicapped child, while her other children were sent to school in Berlin. She also improved in German, and took French and music lesions. She also spent time with an American cousin who was married in the old university town of Göttingen.

She went back to America, disappointed by the lack of improvement of her child's health, despite all these sacrifices. Life took back its course in San Francisco. It was very comfortable. We were following classes at 'High School Valencia Street', which was very well organized for discipline and hygiene. It was a mixed school, with boys and girls sitting in two columns, but with separate playgrounds. At home, nothing was spared for our education, including a German teacher, a music teacher, a dance teacher, a drawing teacher and visits to the zoological garden. At 10 years, I could read German. I also received the Iliad and the Odyssey, Grimm's tales, Andersen's tales, which I read with passion.

Then, my brother (1868) and my younger sister (1870) were born.

During my mother's stay in Europe, my parents marriage deteriorated. When my mother noticed that, after my younger sister was born, she did not accept the situation, and requested legal separation. She obtained it with all rights, including the children responsibility; and, in a sad mood, she embarked for Europe with her six children in April, 1871, claiming that she would raise her daughters in a way that they could become self-sufficient. She went to stay with her cousin in Göttingen. She put my elder sister and me at a boarding school in Canstatt, near Stuttgart (Württemberg). Her cousin in Göttingen took care of the other children. The settlement of my mother's situation necessitated two trips to America. Two years passed. When everything was settled, my mother reunified her six children and went in 1873 to live above Clarens, near Lake Geneva. Later, my father remarried.

During the 2 years at the boarding school in Canstatt, my sister and I had started French lessons; one hour teaching, two hours conversation and reading during our sewing lesson, not including further conversation during our walk when our dear French teacher was accompanying us. After 2 years, I knew enough French to be able to follow classes in French at 'L'Ecole Supérieure de Jeunes Filles' in Lausanne. My mother sent me to stay with one of the school teachers. I was following courses, and I also enjoyed helping one of my teacher's nephews with all his college homework. I worked this way for 3 years.

Then, for the education of my younger sisters, my mother settled in Lausanne. My elder sister studied at home, and since she was keen on painting, she was directed to drawing lessons. My younger sisters went to the 'Ecole Supérieure de Jeunes Filles', where I was already following courses, and my brother went to college (secondary school, in Switzerland).

Thanks to my mother, I had lessons of ancient languages, sciences, mainly chemistry, natural history by professors at the university. After I passed examinations and obtained diplomas, it had been planned that I would become a teacher. However, one day, while opening a fashion magazine, 'La Mode Illustrée' published by Firmin Didot, my mother read that a woman, Mrs Madeleine Brès, had passed her doctorate thesis in medicine at the medical faculty in Paris. She then remembered a comment made by our dear family doctor in San Francisco: 'Madam, if you can make a physician of your second daughter, go ahead'.

I accepted her proposal with enthusiasm; to go to medical school, this was for me the continuation of my studies in sciences, which I liked. But what could my mother do with her daughter? There was still no medical faculty in Geneva or Lausanne; there was one in Zürich, but my mother feared for me the presence there of nihilist Russian student girls, who, for most of them, were dressing like men.

Then, during our mountain vacation in 1876, she met a Parisian lady: 'What, madam, you will be separated from your children, with one daughter in Rome or $\mathrm{Mu}-$ nich for artistic studies, the other one perhaps in hell in 
Zürich, and you with your other children in Lausanne; why don't you come to Paris, you will find there any possible resource you need: atelier de peinture, courses at the medical faculty and the Sorbonne, excellent schools for your son, teaching for your younger children, and you will not be separated from them'.

In September, 1877, my mother went to Paris, and met with the secretary of the Faculty of Medicine, the secretary of the Faculty of Sciences at La Sorbonne, the director of 'Académie Julian' (a famous art school), the provost of 'Lycée Louis-Le-Grand' and the director of a girl school on Gay-Lussac road, and she rented an apartment. In October, we were all in Paris and at work.

Subsequently, my sister obtained twice the Julian award in a contest involving all artistic fields, with women and men. She obtained the silver medal at the Versailles Exhibit, the silver medal at the Philadelphia Exhibit and the bronze medal at the 1889 Universal Exhibit. She was the pupil of Dony Robert Fleury, Jules Lefevre, Vuillefroy and Rosa Bonheur, who legated to her all her estate at her death. She still exhibits works every year at the 'Salon des Artistes Français', has paintings at Metropolitan Museum in New York and museums in Pittsburgh, Chicago, San Francisco, Buenos Aires, etc. She wrote a biography of Rosa Bonheur, founded the Rosa Bonheur prize (1,500 francs) at the 'Société des Artistes Français', and organized the Rosa Bonheur room at the Fontainebleau palace. During the war, she set up a benevolent hospital in Rosa Bonheur's house, covering all costs together with my mother and a group of American friends. From 1914 to 1916, she received convalescent soldiers from the Fontainebleau hospital, from 1917 to 1919 paraplegies from the 'Hôpital des Invalides' in Paris. She has received the silver medal of the 'Reconnaissance Française' and she has just been awarded the 'Légion d'Honneur' (August 1924) by the Ministry of Foreign Affairs upon a proposal by the Ministry of Arts.

The second of the children is myself, Mrs DejerineKlumpke.

The third and the fourth were preparing the elementary diploma at Miss Violet's School, rue Gay-Lussac.

The third child, Mrs Isaac Roberts, born Dorothee Klumpke subsequently worked at home with a secondary school teacher and obtained a masters degree and a doctorate in sciences-mathematics at the Sorbonne. It was the first Sorbonne thesis ever to be presented by a woman (1893). She passed with all honors. During her license, she had applied to the Paris Observatory, where she was admitted by the director, Admiral Mouchez and his family, in a charming and exquisite way. This relationship lasted for over 40 years and is still active. She did several expeditions on free balloons for astronomical studies, made a trip to Cap Nord (astronomical cruise) and was director of the measurements office and the sky photographic map at the observatory. She married an English astronomer, Isaac Roberts, who was a member of the Royal Society in London, and who realized the first photographs of nebulenses. After his death, she concentrated on the study of nebulenses, and presently represents France at the International Committee for the Sky Photographic Map (nebulenses section).

The fourth child, Mathilda Klumpke, followed music lessons with Mrs Doumic at the conservatory; she was Leconpey's and Marmontel's pupil, and became an excellent pianist. She married an American lawyer from Cincinnati, and died young in 1893, from diphteria while caring for her sick children.

The fifth child, John William Klumpke, was mostly educated at 'Lycée Louis-le-Grand' and became an engineer in America.

The sixth child, Julia Klumpke, a student at 'Lycée Fénelon', studied the violin with M. Remy and Isaye. For a long time, she was a violin teacher at the Spartanbourg Girls College, South Carolina (USA).

It seems to me that my beloved good mother has not too badly succeeded in her children's education. To her goes all the merit. She was an admirable mother, with a noble soul, high feelings and total commitment. She was living only for her children. She taught us not to give up when faced with difficulties, to perseverate and to will.

Thanks to her, we were privileged among the girl students in Paris, who were usually foreign and isolated. She knew how to create a warm, maternal, hospitable and sunny home, always decorated with flowers, where her smiling and acting goodness radiated. She ran her household with wise economy, and surrounded us with beauty of nature, art and heart. We were her pride and joy, and for us she was everything. She died at the age of 88 years, still of sound mind, on May 11, 1924, in Rosa Bonheur's house in By par Thomery (Seine et Marne): at the dawn of a beautiful night with full moon, while the nightingale was singing in close-by woods, she started to sing the Titanic passengers song: 'Nearer my Lord to thes'. I said:

'- Dear Mom, we are all around your bed, don't you want to bless your children?

- Oh! My children, I love you so tenderly. God bless you. Be true and just, with a big generous heart, and $\mathrm{He}$ will show you the path to follow'.

She now rests at the 'Père Lachaise', beside Prof. Déjerine and my brother. 
I am now coming to the second child, i.e. myself, and my medical studies. Thanks to my diplomas from Lausanne, I was immediately granted, in 1876 , the equivalent of the baccalauréatés lettres and baccalauréatés sciences reduced for the study of Medicine.

First year - a sciences year at the Faculty of Medicine. Besides, I was also following the sciences courses at $\mathrm{La}$ Sorbonne (Prof. Wurtz, Henri H. Claire Deville), Prof. Frény's course at the Museum, where I got the honor to be received by him in his laboratory. I was able to work quietly away from the turbulent youth of the Faculty of Medicine.

Second year - a year of anatomy and dissection, in the building of the Free Teaching (Prof. J.A. Fort). Prof. J.A. Fort gave an intensive course: two anatomy lessons per day, three hours of dissection with an examination. I followed his teaching for three winters and worked as his assistant for 2 years. At a contest in which his students and candidates for the Internship of the Paris Hospitals participated, I received the 'Anatomy Prize of the Free Teaching', for 1878-1879 ('Médaille de Vermeil', worth 100-400 francs).

Already during my first year in anatomy, Mr. J.A. Fort persuaded me to request from the director of the "Assistance Publique' the authorization to participate in the contest of the externship of the Paris hospitals. I renewed this request the following years. The authorization was regularly rejected, 'female medical students being not authorized to join the contest for externship or internship of the Paris hospitals'.

I was spending the mornings at the hospital, the Pitié Hospital in the services of medicine of Dr. Lancereaux (1878), Dr. Gallard (1878) and Prof. Jaccoud (1879), Saint-Louis Hospital in the surgical service of De Terrillon (1879) and Lariboisière in the surgical service of Prof. Duplay (1879).

During the summer semesters, I was spending the afternoons following the consultation of Dr. Fienzal at the Quinze-Vingts Hospital, where I became even attached as 'Foreign Extern'. I was working in the histology laboratory of Dr. Latteux, and was following the histology courses of Professor Ranvier at the 'Collège de France'.

On Sunday mornings, I was following the clinical lessons of Charcot at La Salpétrière Hospital or of Magnan at the Sainte-Anne Asylum.

In 1880, I entered as an intern in the medical clinic service of Prof. Hardy at the Charité Hospital. Mr Déjerine was head of the clinic, and Mr Landouzy, who was a hospital doctor and associate professor, was giving the 'holiday course'. I stayed two years in Prof. Hardy's ser- vice, from 1880 to 1881 . This was the place where I became initiated to scientific research. I was following clinical activities and lessons, taking histories with patients, going back to the hospital in the afternoon to examine newly admitted patients and performing autopsies. I was given the responsibility of some histological examinations. Besides, my knowledge of foreign languages allowed me to take better advantage of medical texts. Thus, I initiated myself to the English and German medical literature. I read original papers, consulted textbooks and compared published observations with inpatients in our service. I was instructing myself and shaping my mind. These years were much more interesting than the mere study of books for preparing an examination.

Prof. and Mrs Hardy invited me at their home with great benevolence, and I am deeply indebted to them for this. I was introduced to the high French medical society. Mrs Hardy's evenings were very new for me, a foreigner who had spent her youth studying and had never been to such invitations.

In 1882, I was involved in obstetrics at Saint-Louis Hospital in Dr. Porak's service and children diseases in Prof. Grancher's service. I passed several doctorate examinations. During that same year, thanks to the efforts and intense campaign by Miss Edwards, women were admitted to the contest for the externship of the Paris hospitals. I prepared myself for the contest in the "externship conference' of M. Queyrat and Auguste Broca, and both of us succeeded after being admitted to the contest.

My first externship year (1883) was spent in the 'Hôtel-Dieu' Hospital in the service of Dr. Empis. This was taking place very early in the morning, and since it was finished at 8 a.m., it allowed me to follow Charcot's clinical neurological lessons at La Salpétrière, Magnan's psychiatry consultations at Saint-Anne asylum, Prof. Germain Sée's clinical lessons at 'Hôtel-Dieu' and clinical dermatology and syphiligraphy lessons of Prof. Alfred Fournier, Dr. Besnier and Dr. Lailler and Saint-Louis Hospital.

It was in the service of my dear mentor Empis that I was given the possibility to study my first observation of superior brachial plexus radicular palsy (Duchenne Erb type). My attention had been drawn to this topic by chance the preceding year while reading the original work by Erb, a professor from Heidelberg. I was very happy to have been able to make that diagnosis in my little patient, thanks to this reading.

I was lucky to accomplish my second and third externship years (1884 and 1885) at 'Hôtel-Dieu' in the service of the eminent mentor Professor Vulpian. This was an 


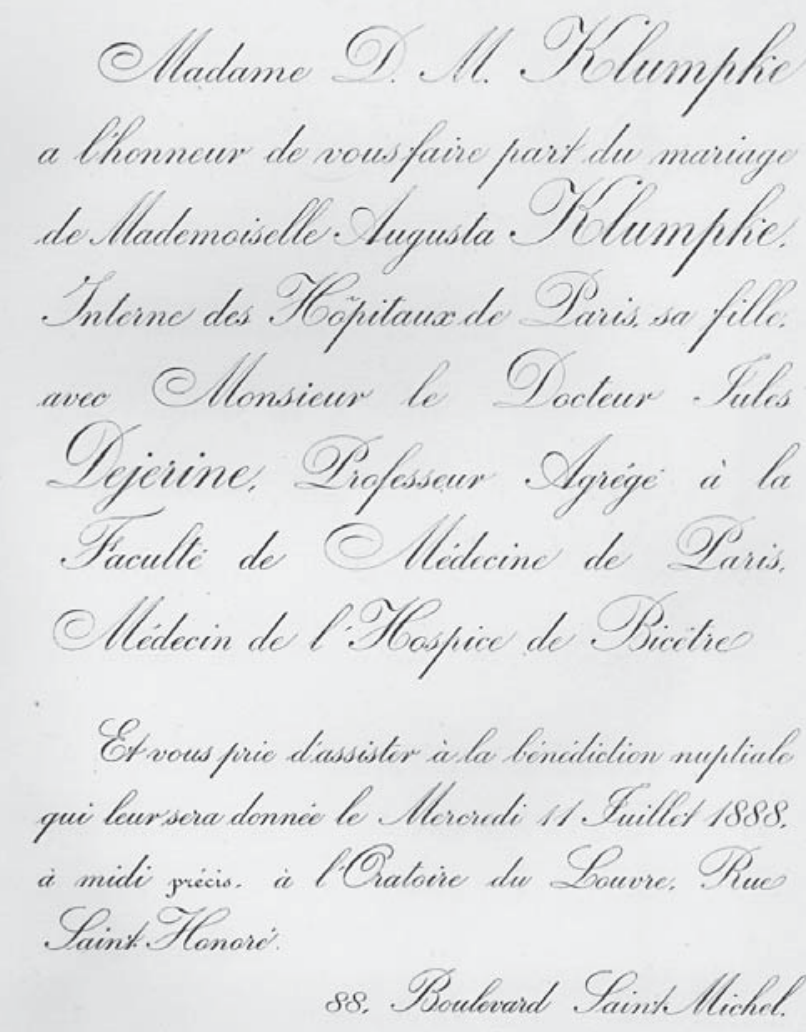

Fig. 3. Announcement of the marriage between Jules Déjerine and Augusta Klumpke, July 14, 1888 at L'oratoire du Louvre in Paris.

excellent general medicine service, with a very large neurological consultation.

It was at this consultation that I had the luck to make a diagnosis of a total brachial plexus radicular paralysis with oculopupillary involvement in a patient. I developed a series of experiments on this subject in the Experimental Pathology Laboratory of Prof. Vulpian. The resulting documents were to become the basis of my doctorate thesis, in the case we would not be authorized to take part in the contest for the internship of the Paris hospitals.

Thanks to the efforts and requests of Miss Edwards, the authorization was given to us in 1885 , and my work was published in the Revue de Médecine the same year. It obtained the Godard Prize (1886) of the Academy of
Medicine. Since then, this type of radicular palsy has been given the name 'Klumpke type of brachial plexus radicular palsy' in the French and foreign literature.

Already during our first externship year, although our admission to the internship contest was unlikely, Miss Edwards and I were following internship lessons under Mr Queyrat, $\mathrm{Mr}$ Legendre and $\mathrm{Mr}$ de Colleville. $\mathrm{Mr}$ Queyrat was very good to us and gave use a specific teaching to train ourselves for this so special preparation to the contest.

Miss Edwards made request after request. The fight was intense, and the tension became particularly acute during spring 1885 , when all preparation courses were closed to us. In July, we did not know if we would be authorized to take the contest in October. In August, we were admitted by the Prefect of the Seine, despite the negative advice from the Dean of the Faculty, the Medical Society of Hospitals and the Surgical Society of the Hospitals in a plenary session, the Surveillance Council of the 'Assistance Publique', and contrary to the advice of the Association of the Former Interns of the Paris Hospitals.

In fact, it was a political decision, which we owed to Paul Bert, who was Minister, and who belonged to the developing movement of women emancipation and organization of secondary schools for girls.

I took the internship contest in 1885 and 1886. In 1885 , I was appointed second temporary intern, and in 1886, sixteenth full intern. At the written examinations, I got each time the highest mark given at these contests.

My health had been slightly affected by this working life, together with anxiety and fights for the contest. I needed a rest, and my physician advised a stay in Italy, so I spent two months in Florence with my elder sister.

On my return, in 1886, I replaced interns, and worked as a temporary intern during 4 months in the surgical service of Prof. Paul Berger and Dr. Gérard Marchant. At the end of 1886, I did another intern replacement at 'Hôtel-Dieu' in the service of my dear mentor Empis (service of medicine). The attitude of the interns towards me was irreproachable, as it was to be during all my work as a titular intern.

In 1887, I did my first year as a titular intern in Dr. Balzer's service at 'L'Hôpital de Lourcine', now Broca Hospital.

In 1888, I did my second year at Tenon Hospital in the service of my dear mentor Prof. Landouzy (service of medicine and newborns). Then, I got married (fig. 3) and my internship was interrupted. 


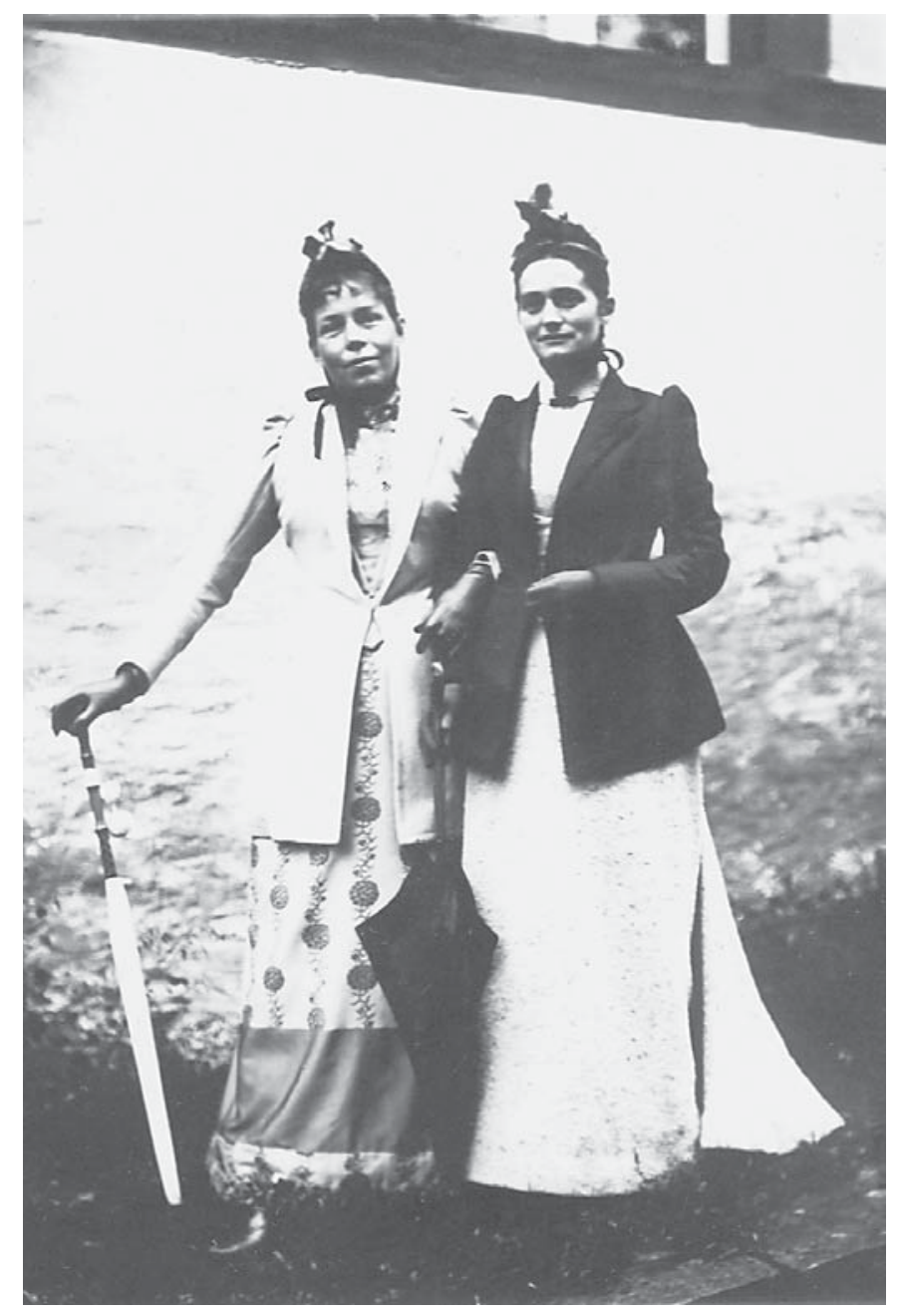

Fig. 4. Augusta Klumpke (left) at the age of 30 years with the wife of Dr. Paul Dubois, a Swiss psychiatrist and close friend of Jules Déjerine.

My doctoral thesis was accepted in 1889 , for which most documents had been collected during my 2 years of externship in the service of my eminent mentor Vulpian at 'Hôtel-Dieu', or in Mr Déjerine's service at 'Bicêtre'. The title of my thesis was 'Des polynévrites en général et des paralysies et atrophies saturnines en particulier. Etude clinique et anatomo-pathologique.' (About polyneuritis in general and saturnian palsies and atrophies in particular. Clinical and anatomopathological study.) It was won the silver medal at the Paris Faculty of Medicine and the Lallemand Prize (1890) at the Academy of Sciences ('Institut de France').

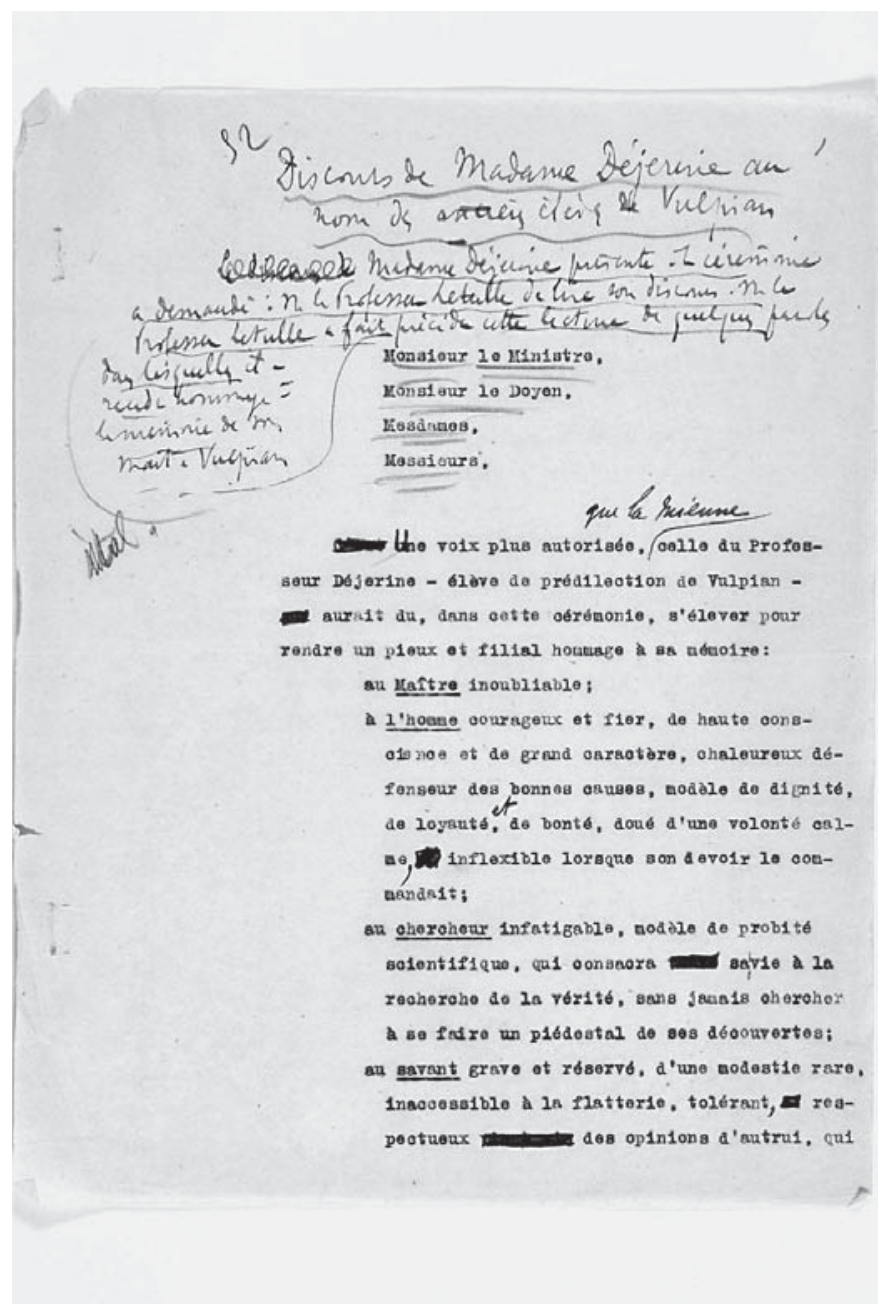

Fig. 5. First page of proofs of Augusta Déjerine-Klumpke's speech at the celebration of the centenary of the birth of Vulpian.

\section{Conclusion}

This text shows an extraordinary dynamism in this young American girl, who came to Paris to study medicine, and finally became one of the first women in France to obtain a hospital position, first as an extern, and then as an intern, before contributing to major topics in neurology, with or without her husband Jules Déjerine, with whom she had formed a famous and critically efficient team. From 1885 to 1926 we have recorded 56 important publications by Augusta Déjerine-Klumpke, without including her critical contribution to Jules Déjerine's textbooks. She was also the first woman to become president of the French Society of Neurology, in 1914. Her last of- 
ficial contribution was her speech on the occasion of the celebration of the centenary of Vulpian's birth (fig. 5); shortly before she passed away at the age of 68 years. The present document gives an interesting, lively perspective on her youth years, which made this young woman in the position to obtain unexpected achievements.

\section{Acknowledgement}

We would like to thank Mr Jean-Claude Sorrel-Déjerine for his invaluable help. The help of Sebastian Dieguez was also appreciated.

\section{Recommended Reading}

1 Thomas A, Roussy G, Roger, Letulle M, Babonnex, Baudoin A, Haskovec, Heuyer G, Jelliffe SE, Long E, Massini LC, Pagniez, Spiller WG, Thuiller-Landry L: Madame Déjerine, 1859-1927.

2 Sorrel-Déjerine Y: Madame Déjerine-Klumpke (1859-1927). Presse Med 1959;67:19971999.
3 Roch-Lecours A, Caplan D: Augusta DéjerineKlumpke 'The lesson of anatomy'. Brain Cogn 1984;3:166-197.

4 Satran R: Augusta Déjerine-Klumpke. First woman intern in Paris hospitals. Ann Intern Med 1974;80:260-264.

5 Roch-Lecours A, Chain F, Poncet M, Nespoulos JL, Joanette Y: Paris 1908: The hot Summer of aphasiology or a season in the life of a chair. Brain Lang 1992;42:105-152.
6 Gauckler E: Le professeur J. Déjerine, 18491917. Masson, Paris, 1922.

7 Sorrel-Déjerine JC: Personal communication, 2004.

8 Bonduelle M: De la Revue Neurologique à la Société de Neurologie. Rev Neurol 1995; 151 : 307-310. 